\title{
Habitat manipulation to mitigate the impacts of invasive arthropod pests
}

Mattias Jonsson $^{1 *}$, Steve D. Wratten ${ }^{1}$, Doug A. Landis ${ }^{2}$, Jean-Marie L. Tompkins ${ }^{1}$ and Ross Cullen ${ }^{3}$

${ }^{1}$ Bio-Protection Research Centre, PO Box 84, Lincoln University, Lincoln 7647, New Zealand, ${ }^{2}$ Department of Entomology, 204 Center for Integrated Plant Systems, Michigan State University, E. Lansing, Michigan 48824-1311, USA, ${ }^{3}$ Faculty of Commerce, PO Box 84, Lincoln University, Lincoln 7647, New Zealand

* corresponding author: email: mattias.jonsson@lincoln.ac.nz, phone: +64-33218387, fax: +64-3-3253864

\footnotetext{
Abstract Exotic invaders are some of the most serious insect pests of agricultural crops around the globe. Increasingly, the structure of landscape and habitat is recognized as having a major influence on both insect pests and their natural enemies. Habitat manipulation that aims at conserving natural enemies can potentially contribute to safer and more effective control of invasive pests. In this paper, we review habitat management experiments, published during the last ten years, which have aimed to improve biological control of invasive pests. We then discuss during what conditions habitat management to conserve natural enemies is likely to be effective and how the likelihood of success of such methods can be improved. We finally suggest an ecologically driven research agenda for habitat management programmes.
} 
Keywords: conservation biological control; ecosystem services; habitat management; pest management 


\section{Introduction}

Exotic invaders are some of the most serious arthropod pests in agricultural

landscapes. In the USA, for example, introduced arthropod pests have been estimated to cause losses worth around $\$ 20$ billion each year (Pimentel et al. 2005). For many of these invasive pests, chemical pesticides are still the dominant form of control, contributing to additional costs in the form of degraded environmental and human health (Mack et al. 2000; Paoletti and Pimentel 2000). Classical biological control, i.e., the intentional introduction of exotic natural enemies, has had some spectacular successes in controlling invasive pests (Zeddies et al. 2001; Menzler-Hokkanen 2006), but only about $10 \%$ of all introductions have contributed to management of the targeted arthropod pests (Greathead and Greathead 1992; Gurr and Wratten 2000). It has been suggested that low availability of key resources for natural enemies, such as alternative food and overwintering sites, in many agroecosystems is one reason limiting biological control effectiveness (Gurr and Wratten 1999). Support for this hypothesis comes from various studies showing that density and diversity of natural enemies tend to be higher in landscapes with a high proportion of non-crop vegetation (see Bianchi et al. 2006 for a review). Habitat management can be used to provide natural enemies with resources that can be limiting in agroecosystems (Barbosa 1998; Pickett and Bugg 1998; Landis et al. 2000; Gurr et al. 2004; Jonsson et al. 2008). This approach can lead to improved biological control, but it often requires in-depth knowledge of the natural enemies and the most appropriate, selective resources to deploy. In this paper we discuss how habitat management can be used to conserve natural enemies of invasive pests. We first give a general introduction to habitat management and review how successful this approach has been to improve biological 
control of invasive pests to date. We then discuss under what circumstances different types of habitat management are likely to be effective, and how the likelihood of success can be improved. Based on this, we finally propose an ecologically driven research agenda to inform development of habitat management programmes for invasive pests.

\section{Habitat management and biological control}

The potential for pest management through habitat manipulation has long been recognised. Elton (1958) and Pimentel (1961) suggested that outbreaks of pest insects are less likely in diverse crop situations than in monocultures. Root (1973) found that pest populations were lower in polycultures of collard (kale) and meadow vegetation compared to collard monocultures. He identified two potential mechanisms behind such patterns: the 'resource concentration' hypothesis where specialist herbivores are less likely to find and remain on host plants within a polyculture and the 'enemies' hypothesis where natural enemies are more effective in diverse crop environments (Root 1973). We concentrate this review on effects relating to the 'enemies' hypothesis.

The 'enemies' hypothesis implies that habitat management can be used to conserve and enhance natural enemies (Pickett and Bugg 1998; Landis et al. 2000). This type of conservation biological control can provide natural enemies with a favourable microclimate, shelter, hibernation sites and alternative food sources, such as nectar, pollen and alternative prey (Landis et al. 2000). One of the most well-known habitat 
management techniques to conserve natural enemies is the provision of beetle banks. These are usually grass covered earth banks located in the middle of a field (Thomas et al. 1991, 1992). These banks can provide overwintering sites for ground living predatory beetles in the families Carabidae and Staphylinidae and for spiders and this can increase their density (Thomas et al. 1991, 1992) and diversity (MacLeod et al. 2004). Predation has been found to increase close to beetle banks (Collins et al. 2002), but this effect is not universal (Prasad and Snyder 2006). Other ecological advantages of the banks are that relatively rare European farmland bird and mammal species nest on, and hunt along them (Thomas et al. 2001).

Another well-known type of habitat management to conserve natural enemies is the sowing of flower strips to provide nectar and pollen as food sources for natural enemies (Pfiffner and Wyss 2004; Gurr et al. 2005; Heimpel and Jervis 2005). One example where this approach has been successful is in the control of the light-brown apple moth (Epiphyas postvittana (Walker)), an invasive leafroller (Lepidoptera: Tortricidae) in New Zealand. This species, which originated from Australia (Danthanarayana 1975), is considered one of the most important pests on grapes, apples and other horticultural crops in New Zealand, especially on the South Island (Scott 1984). Availability of flowering buckwheat (Fagopyrum esculentum Moench) (Scarratt 2005) and alyssum (Lobularia maritima (L.)) (Berndt and Wratten 2005) can increase fecundity and longevity and increase the proportion of female offspring of Dolichogenidea tasmanica Cameron, a key parasitoid of the leafrollers. Parasitism rates and leafroller densities have been shown to increase and decrease respectively in vineyards close to buckwheat and alyssum (Scarratt 2005; Irvin et al. 2006), although 
increased parasitism rates and/or decreased pest densities has not been achieved in all trials (Berndt et al. 2002; Berndt et al. 2006). Recent unpublished data indicate that leafroller densities can in some cases be reduced to below the economic threshold when flowering buckwheat is available. Provision of buckwheat has now been adopted as a measure to control leafrollers in vineyards in all major wine regions of New Zealand (Figure 1).

'Success' of habitat management trials

Several reviews have been published on the 'success rate' of habitat management trials. Andow (1991) found that polyculture led to decreased insect pest densities in $52 \%$ of studies compared with $15 \%$ of such studies where pest densities were higher in polycultures. Many of these studies did not distinguish between the 'resource concentration' and the 'enemies' hypothesis, but based on indirect evidence it was suggested that positive processes related to the former are more common (Andow 1991). Thus, although we here concentrate on effects mediated by natural enemies, it must be acknowledged that effects relating to the 'resource concentration' hypothesis can be significant.

Gurr et al. (2000) reviewed studies of habitat management for conservation biological control published during the 1990s and found that 19/22 studies reported positive effects on natural enemy populations while 15/22 showed lower pest densities. Of these, only 4/8 showed positive effects on the yield or quality of the crop. More recently, Heimpel and Jervis (2005) reviewed evidence that floral nectar improves 
biological control by parasitoids. In 7/20 of the reviewed studies, parasitism rates increased with floral nectar sources available, but in only one study was a concomitant decrease in pest density recorded.

We conducted a similar analysis of habitat management experiments published between 1998 and 2007 aimed at improving biological control of invasive pests. We considered only peer-reviewed journal articles presenting results from open field trials where the effect of habitat manipulation on invasive pests was studied either through assessment of parasitism or predation rates and/or of pest population densities. Studies that did not estimate these rates were considered only if the effects on both natural enemy and pest densities were measured. We found 15 studies fulfilling these criteria (Table 1). Fourteen of the 15 papers reported at least some positive effects of habitat manipulation on either population densities of natural enemies or on predation or parasitism rates, whereas one study found that habitat manipulation decreased predation rates. The latter occurred probably because Harmonia axyridis Pallas (Coleoptera: Coccinellidae), a key predator of the rosy apple aphid, Dysaphis plantaginea (Passerini), was feeding on extrafloral nectaries on peach trees instead of the pest (Spellman et al. 2006; Brown and Mathews 2007). In 4/7 studies, pest densities decreased following habitat manipulation and in one the pest population increased close to the flower strips that were provided, probably because the pest itself was attracted to and feeding from the flowers (Baggen and Gurr 1998; Baggen et al. 1999). In one of the studies that found a negative effect of habitat management on pest populations the effect on predation rate was also negative (Brown and Mathews 2007). It was suggested that the mechanism behind decreasing pest 
populations in this case was related to the resource concentration hypothesis (Root 1973) rather than through improved biological control. Three of the 15 studies considered effects on either crop damage or yield, but none of these studies reported beneficial effects. Baggen and Gurr (1998) reported increased pest damage close to certain floral subsidies probably because the pest was exploiting those floral resources, whereas Schmidt et al. (2007) found that alfalfa grown as a cover crop decreased crop yield in soybean most likely because the alfalfa competed with the crop. The latter was the only study that considered economic consequences of habitat management and it concluded that it was not cost effective (Schmidt et al. 2007).

\section{When is habitat management likely to be successful?}

Here we discuss factors that are likely to affect the outcome of habitat management experiments, and that can help explain the mixed effectiveness of such trials to date. Success of habitat management is likely to depend both on the composition of the local food web and the extent to which suitable and limiting resources are provided that target the right natural enemies.

Selecting target species

A first prerequisite for habitat management to improve biological control is that potentially effective natural enemies are available in the food web of the targeted herbivore. Invasive species may frequently lack specialist natural enemies and this may require introductions of the latter through classical biological control programmes. Although habitat manipulation was initially developed to support native 
natural enemies, this approach can be useful for conserving introduced natural enemies as well (Gurr and Wratten 1999).

A continuing discussion relates to whether one or multiple natural enemies are needed for effective biological control. In many cases success of classical biological control programmes has been attributed to single species, even if multiple species have been introduced (Denoth et al. 2002). However, experiments explicitly studying the relationship between natural enemy diversity and biological control suggest that this relationship is highly idiosyncratic (Straub et al. 2008). One way that increasing natural enemy diversity may positively affect biological control is through the 'sampling' effect. This implies that with increasing diversity in a natural enemy community it is more likely that particularly effective species are present. Thus, the 'sampling' effect is not an effect of diversity per se but relies on species' identity and properties. Several studies have shown that species identity is an important factor in prey suppression (Schmitz and Suttle 2001; Chalcraft and Resetarits 2003; Straub and Snyder 2006). Cardinale et al. (2006) argued that the 'sampling' effect is often a main driver of diversity - ecosystem function relationships. If the only benefit from increasing natural enemy diversity for biological control is that the most effective natural enemy is more likely to be present, then it may be most efficient to identify that species by experiment and then target it in habitat management measures (Snyder et al. 2006).

Several studies have found a positive relationship between natural enemy diversity per se and biological control (Aquilono et al. 2005; Snyder et al. 2006; Straub and 
Snyder 2008). Such effects can occur when the feeding niches of different natural enemy species complement each other. Two mechanisms that can lead to niche complementarity are resource partitioning and facilitation. Resource partitioning occurs, for example, when different natural enemy species forage on different parts of a plant (Straub and Snyder 2008), when they attack different life stages of the pest (Wilby and Thomas 2002) or feed on different pest species (Finke and Snyder 2008). Facilitation implies that the presence of one natural enemy species facilitates feeding by another species. Losey and Denno (1998) studied consumption of pea aphids, Acyrthosiphon pisum Harris, by one foliage living and one ground living predator and found that aphid consumption was the highest when both predator species were present. In the presence of the foliage living predator aphids dropped off the plant and became accessible for predation by the ground living predator. If niche complementarity is important in a natural enemy community, it may be most effective to target functionally complementary species of natural enemies in habitat management measures. This can be done, for example, by supplying a combination of resources that benefit ground living and foliage living natural enemies. Frank and Shrewsbury (2004) combined beetle banks and flower strips to support ground living and foliage living natural enemies and found a positive effect on predation rates of turf grass pests on golf course fairways. However, this study did not compare the combined effect of flower strips and beetle banks with the effect of these two measures separately, so it could not be concluded whether combining the two measures created a stronger effect on biological control. 
In some cases increasing natural enemy diversity may have a negative effect on biological control because of intra-guild predation or inter-specific interference (Rosenheim et al. 1993; Finke and Denno 2004, 2005; Costamagna et al. 2008). Prasad and Snyder (2006) evaluated the effect of beetle banks in vegetable crops in NW USA and SW Canada. It was found that beetle banks provided through the winter increased the density of predatory beetles in the field during the following crop season, but predation rate of sentinel fly eggs in the crop was unaffected. Further experimentation suggested that intra-guild predation by a large predatory beetle was partly responsible for this lack of effect on predation rate. Thus, if intra-guild predation is strong, habitat management may not improve biological control, although it conserves individual natural enemies. However, habitat manipulation may in some cases decrease the intensity of intra-guild predation. Finke and Denno (2006) showed that by adding structural diversity in the form of thatch to a salt marsh food web, intra-guild predation decreased and predation on a plant hopper herbivore increased. The mechanism was that thatch provided a refuge from intra-guild predation for a predatory mirid bug. The potential for habitat management to decrease negative interactions among natural enemies in crop systems has not been studied.

The local species pool of natural enemies in the crop is partly dependent on the composition of the landscape surrounding the field. Fields located in complex landscapes with a low proportion of annual crops and a high diversity of other vegetation types tend to have a higher diversity of natural enemies than do fields in simpler landscapes dominated by agriculture (Öberg et al. 2007; Schmidt et al. 2008; Gardiner et al. 2009a). Landscape structure may particularly affect beta diversity, i.e. 
the difference in species composition among sites (Tscharntke et al. 2008). A high beta diversity may be important as an insurance against fluctuating environmental conditions (insurance hypothesis; Yachi and Loreau 1999; Tscharntke et al. 2008). If different natural enemy species are effective during different environmental conditions, seemingly redundant species may become important in reducing pest populations in certain situations. The effect of the insurance hypothesis on biological control has not been rigorously tested, however (Tscharntke et al. 2008).

Selecting resources to provide

To be successful, habitat management should provide natural enemies with suitable resources that are limiting for these species and that do not invoke unwanted side effects. A convenient way of screening large numbers of food plants is to study visitation rates of natural enemies in the field (Fiedler and Landis 2007a, b). This method can give information about attractiveness of food plants, which is an important factor to consider when selecting which plant species to provide for biological control (Kean et al. 2003; Bianchi and Wäckers 2008). However, flower attractiveness is not strictly related to other floral attributes such as nectar accessibility (Wäckers 2004), so additional experiments are needed to fully evaluate the suitability of flowering plants for natural enemies. Laboratory studies can be used to assess the suitability of food plants by studying how they affect various natural enemy traits including longevity and fecundity (Baggen and Gurr 1998; Tylianakis et al. 2004; Robinson et al. 2008), sex-ratio (Berndt and Wratten 2005) and dispersal ability (Wanner et al. 2006) that are all likely to influence natural enemy efficacy. However, laboratory trials are not enough to predict how resource provision will 
affect natural enemies in the field. Unequivocal evidence that resources such as nectar and shelter are limiting for natural enemies in agroecosystems is rare. However, Lee and Heimpel (2008) showed that nectar feeding on floral resource subsidies by the parasitoid Diadegma insulare (Cresson) in the field can lead to increased gut content of sugars and improved longevity and fecundity. This study thus provided unique evidence that parasitoids can be sugar limited in the field and that provision of floral resource subsidies can help remedy this.

The extent to which certain resources are limiting for natural enemies will depend on what is available within the crop (extrafloral nectaries, honeydew, flowering weeds, alternative prey etc), but also on the composition of the landscape surrounding the field. Thies and Tscharntke (1999) found higher parasitism rates on rape pollen beetles close to the field edge compared to in the centre in structurally simple landscapes dominated by agriculture but no such effect was found in complex landscapes. It has also been shown that conversion to organic farming has the largest effect on spider density in wheat fields in simple landscapes (Schmidt et al. 2005). Both these studies suggest that resource availability in the surrounding landscape is likely to influence the effectiveness of local schemes to conserve natural enemies.

Avoiding negative side effects

The provision of resources through habitat management can in some cases decrease natural enemy attack rates on the pest although the resource is suitable for the targeted natural enemy. For predators that are true omnivores, i.e., they feed on prey and plantprovided resources in one life stage, decreased predation rates may occur because the 
predator becomes satiated through feeding on plant resources. Provision of nectar and pollen can decrease the predation rate by ladybeetles (Spellman et al. 2006; Brown and Mathews 2007), predatory mites (Wei and Walde 1997) and brown lacewings (Robinson et al. 2008). In a similar way, presence of alternative prey for generalist predators may in some cases decrease predation rates on the target pest (Prasad and Snyder 2006). The impact of plant resources and alternative prey on true omnivores and generalist predators respectively is likely to depend on how different resources are distributed in time and space (van Rijn and Sabelis 2005). For such natural enemies, availability of alternative food resources may improve biological control primarily when the target pest is scarce (Polis and Strong 1996; Eubanks and Styrsky 2005; Jonsson et al. 2009).

Unwanted side effects of habitat manipulation may also occur if the resources provided benefit the pest itself (Baggen et al. 1999; Begum et al. 2006; Lavandero et al. 2006) or antagonists of natural enemies of the pest (Araj et al. 2008, 2009). Jonsson et al. (2009) studied the effect of flowering buckwheat on four trophic levels, including alfalfa, pea aphids (A. pisum), the omnivorous lacewing Micromus tasmaniae Walker and the lacewing parasitoid Anacharis zealandica Ashmead. $M$. tasmaniae is a true omnivore that feeds on floral nectar and aphids in its adult life stage whereas A. zealandica is a life-history omnivore that feeds only on sugar-rich resources such as nectar as an adult and parasitizes lacewings as larvae. Laboratory trials showed that fecundity and longevity of $M$. tasmaniae is positively affected by floral availability mainly when aphid availability is low (Robinson et al. 2008; Jonsson et al. 2009). In a field cage experiment, provision of flowering buckwheat 
decreased lacewing densities when aphid availability was high, probably because buckwheat primarily benefits the lacewing parasitoid during such conditions (Jonsson et al. 2009). One way to decrease the risk for this type of unwanted side effects is to search for food plants that selectively benefit natural enemies of the pest but not the pest itself or key antagonists (Baggen et al. 1999; Begum et al. 2006; Lavandero et al. 2006; Araj et al. 2008).

Towards informed landscape management

Habitat management experiments have to date mostly been conducted at a local semifield or field scale. However, natural enemy fecundity (Bommarco 1998), density (Schmidt et al. 2005) and species diversity (Öberg et al. 2007; Schmidt et al. 2008) as well as parasitism (Thies and Tscharntke 1999; Thies et al. 2005; Bianchi et al. 2008) and predation rates (Gardiner et al. 2009a) of pests are often strongly influenced by landscape composition, suggesting that it is important to consider large-scale dynamics for habitat management (Bianchi et al. 2006; Tscharntke et al. 2008). Landscape management might be especially important if effective biological control depends on a high diversity of natural enemies (Tscharntke et al. 2008). Local management may increase the density of a few common species whereas species richness often depends more on landscape composition (Roschewitz et al. 2005; Schmidt et al. 2005; Schmidt et al. 2008). The spatial scale to consider for management should ideally depend on the dispersal abilities of the targeted natural enemies. Marked natural enemies have been recaptured at distances around $100 \mathrm{~m}$ away from the refuges where they were marked (Corbett and Rosenheim 1996; Schellhorn et al. 2008) but many natural enemies are likely to move much longer 
distances. Corbett and Rosenheim (1996) found that between 55 - $100 \%$ of Anagrus parasitoids colonising vines in spring had overwintered outside the vineyards, probably in riparian habitats that were located $200 \mathrm{~m}-10 \mathrm{~km}$ away. Several studies correlating landscape composition with parasitism rates of pests have found the strongest effect of landscape structure at around $1 \mathrm{~km}$ diameter around the crop (Thies et al. 2003; Thies et al. 2005; Bianchi et al. 2008), suggesting that dispersal over such distances is common for many parasitoids. Some predators readily move over larger distances; the density of ballooning spiders, for example, correlates strongly with landscape composition at $3 \mathrm{~km}$ diameter around the crop (Schmidt et al. 2008). However, the landscape features of importance for natural enemies depend on the biology of individual species. The availability of certain habitat types such as meadows (Kruess and Tscharntke 1994), forests (Bianchi et al. 2008) and riparian habitats (Corbett and Rosenheim 1996) have all been identified as important for certain natural enemies. Some of these species may also benefit from a high availability of particular crops in the landscape. Gardiner et al. (2009b) found that the ladybeetle Hippodamia convergens Guèrin-Mèneville was more common in landscapes with a high proportion of corn and soybean crops in mid-western USA.

Achieving landscape management will generally require coordinated adoption of habitat management techniques by a group of farmers in an area. Although large-scale adoption of such methods is still very rare globally (Cullen et al. 2008; Griffiths et al. 2008), notable exceptions do exist. Partnerships where farmer groups together trial and adopt agroecological methods at a large scale have recently emerged in different parts of the world, including California, New Zealand and The Netherlands (Warner 2007; Cullen et al. 2008). These partnerships often aim at improving multiple 
ecosystem services, such as soil retention, weed suppression and biological control by deploying non-crop plants (Cullen et al. 2008) and this is probably one important reason for their success (Fiedler et al. 2008). The 'Greening Waipara’ project in the Waipara Valley, in New Zealand, is one such initiative, where to date 46 properties, mostly wineries, work together with researchers at Lincoln University and Landcare Research, New Zealand in an effort to restore native biodiversity to a region currently dominated by intensive agriculture and exotic vegetation (Fiedler et al. 2008; Tompkins 2009; Figure 2). This project began when studies showed that biological control of the light-brown apple moth can be improved if the non-native plant species buckwheat, alyssum and phacelia (Phacelia tanacetifolia Benth.) are drilled between the rows of vines. This led to attempts to find native plants that can have a similar effect (Tompkins 2009) and a focus on how native plants can provide ecosystem services other than biological control and contribute to conservation (Fiedler et al. 2008). Current research projects at Lincoln University explore how the landscape management conducted within the 'Greening Waipara' project affects populations of a range of vineyard pests including grass grubs Costelytra zealandica (White), the New Zealand flower thrips, Thrips obscuratus (Crawford) and leafrollers and their natural enemies.

\section{Conclusions and prospects}

Habitat manipulation experiments have repeatedly demonstrated positive effects on natural enemy populations and/or on parasitism and predation rates but effects on invasive pest populations have been more varied. Few studies have considered effects on crop damage, yield or quality and assessments of the economic consequences of 
habitat management for growers are extremely rare (Cullen et al. 2008). We strongly recommend that such effects are studied more often in the future. Careful ecological economic research conducted at sufficiently large number of sites is needed for development of general management principles for control of invasive species (Leung et al. 2005). This requires integration of ecology and economics to determine optimal responses to invasive species (Shogren and Tschirhart 2005; Ranjan et al. 2008) and consideration of the complexity and uncertainty involved with estimating the costs and benefits of invasive species (Leung et al. 2005).

Our review suggests an ecologically driven research agenda to inform development of habitat management programmes for invasive arthropods (Figure 3). As soon as a target invasive is identified there are a number of key pieces of information that need to be collected. These include clarification of the invader's taxonomic status and elucidation of its life history in the new range. Typically there will also be studies conducted to determine its current and potential future pest status. As part of these initial investigations it is critical to determine if a community of existing natural enemies is utilizing this new resource. In many cases, any such community will likely be dominated by generalist natural enemies. If no potentially effective natural enemies are found, it would either suggest that the species may be a candidate for importation (i.e., classical) biological control. Alternatively, aspects of the invaders life history or pest status may suggest it is unlikely to be amenable to biological control of any sort, and alternative or complementary management strategies should be pursued.

If potentially effective natural enemies are found to exist, next steps include determining existing natural enemy guilds and food web structure. These may be 
compared to those in the invader's native range for clues as to critical missing species, guilds or food web linkages. Intra-guild interactions can be very important in determining the success of any biocontrol effort and need to be examined, as well as determining if keystone species exist in the system (Griffiths et al. 2008; Straub et al. 2008). Again, depending on the results of such studies, importation programmes or alternative strategies may be initiated.

Once key natural enemies are identified, it is necessary to determine if single or multiple species are likely to be most effective and if these species are potentially limited by a lack of critical resources or by particular species interactions. If resource limitation occurs, can selective resources be identified, as well as when, at what spatial scale should they be provided? For practical reasons, many of these studies may be conducted at small spatial scales, i.e. within field cages or small plot experiments. However, for habitat management approaches to be successful it is critical that research rapidly advances to determine the actual effective spatial scales of pest enemy interactions and if landscape-scale dynamics are important (Griffiths et al. 2008; Tscharntke et al. 2008).

Based on these evaluations it should be possible to propose candidate habitat management practices to enhance control of the target invader. Increasingly, any such modifications of agricultural landscapes will need to take into consideration other ecosystem services, such as pollination (Tuell et al. 2008; Isaacs et al. 2009) that could be maintained or enhanced by the same practices. Fielder et al. (2008) suggest that habitat management programmes are uniquely positioned to maximize many of the supporting, provisioning, regulating and even cultural services that society expects 
from its working landscapes. Finally, all of these considerations need to factor into an evaluation of the economic consequences for the growers. Increasingly, it is clear that to achieve such an optimization of ecosystem services, new incentive structures will need to be put in place that fairly value the full range of ecosystem services that working landscapes provide society (Swinton et al. 2006; Sandhu et al. 2008).

Acknowledgements We thank James Harwood for the opportunity to contribute to this special issue and to two anonymous reviewers for helpful comments on the manuscript. We acknowledge the following funding sources: the Tertiary Education Commission, New Zealand, through the Bio-Protection Research Centre, Lincoln University, New Zealand (Mattias Jonsson and Steve Wratten), the New Zealand Foundation for Research, Science and Technology (FRST); project LINX0303 (Steve Wratten, Ross Cullen, Jean Tompkins), Lincoln University, New Zealand, for a Postgraduate Scholarship to Jean Tompkins, USDA CSREES Risk Avoidance and Mitigation Program (2004-51101-02210), USDA NC SARE Project (LCN 04-249), USDA CSREES Arthropod and Nematode Biology (2004-35302-14811), North Central Regional IPM, NSF-LTER at Kellogg Biological Station (NSF DEB 0423627), and the Michigan Agricultural Experiment Station (Doug Landis).

\section{References}

Andow DA (1991) Vegetational diversity and arthropod population response. Annu Rev Entomol 36:561-586 
Aquilono KM, Cardinale BJ, Ives AR (2005) Reciprocal effects of host plant and natural enemy diversity on herbivore suppression: an empirical study of a model tritrophic system. Oikos 108:275-282

Araj SA, Wratten SD, Lister AJ, Buckley HL (2008) Floral diversity, parasitoids and hyperparasitoids - A laboratory approach. Basic Appl Ecol 9:588-597

Araj SA, Wratten SD, Lister AJ, Buckley HL (2009) Adding floral resources to improve biological control: Potential pitfalls of the fourth trophic level Basic Appl Ecol 10.1016/j.baae.2008.12.001

Baggen LR, Gurr GM (1998) The influence of food on Copidosoma koehleri (Hymenoptera: Encyrtidae), and the use of flowering plants as a habitat management tool to enhance biological control of potato moth, Phthorimaea operculella (Lepidoptera: Gelechiidae). Biol Control 11:9-17

Baggen LR, Gurr GM, Meats A (1999) Flowers in tri-trophic systems: mechanisms allowing selective exploitation by insect natural enemies for conservation biological control. Entomol Exp et Appl 91:155-161

Barbosa P (1998) Conservation Biological Control. Academic Press, Sandiego, California, USA

Begum M, Gurr GM, Wratten SD, Hedberg PR, Nicol HI (2006) Using selective food plants to maximize biological control of vineyard pests. J Appl Ecol 43:547-554

Berndt LA, Wratten SD (2005) Effects of alyssum flowers on the longevity, fecundity, and sex ratio of the leafroller parasitoid Dolichogenidea tasmanica. Biol Control 32:65-69

Berndt LA, Wratten SD, Hassan PG (2002) Effects of buckwheat flowers on leafroller (Lepidoptera: Tortricidae) parasitoids in a New Zealand vineyard. Agric Forest Entomol 4:39-45 
Berndt LA, Wratten SD, Scarratt SL (2006) The influence of floral resource subsidies on parasitism rates of leafrollers (Lepidoptera: Tortricidae) in New Zealand vineyards. Biol Control 37:50-55

Bianchi FJJA, Booij CJH, Tscharntke T (2006) Sustainable pest regulation in agricultural landscapes: a review on landscape composition, biodiversity and natural pest control. Proc R Soc B Biol Sci 273:1715-1727

Bianchi FJJA, Goedhart PW, Baveco JM (2008) Enhanced pest control in cabbage crops near forest in The Netherlands. Landsc Ecol 23:595-602

Bianchi FJJA, Wäckers FL (2008) Effects of flower attractiveness and nectar availability in field margins on biological control by parasitoids. Biol Control $46: 400-408$

Bommarco R (1998) Reproduction and energy reserves of a predatory carabid beetle relative to agroecosystem complexity. Ecol Appl 8:846-853

Braman SK, Pendley AF, Corley W (2002) Influence of commercially available wildflower mixes on beneficial arthropod abundance and predation in turfgrass. Environ Entomol 31:564-572

Brown MW, Mathews CR (2007) Conservation biological control of Rosy apple aphid, Dysaphis plantaginea (Passerini), in Eastern North America. Environ Entomol 36:1131-1139

Cardinale BJ, Srivastava DS, Duffy EJ, Wright JP, Downing AL, Sankaran M, Jouseau C (2006) Effects of biodiversity on the functioning of trophic groups and ecosystems. Nature 443:989-992

Chalcraft DR, Resetarits WJ (2003) Predator identity and ecological impacts: functional redundancy or functional diversity? Ecology 84:2407-2418 
Collins KL, Boatman ND, Wilcox A, Holland JM, Chaney K (2002) Influence of beetle banks on cereal aphid predation in winter wheat. Agric Ecosyst Environ 93:337-350

Corbett A, Rosenheim JA (1996) Impact of a natural enemy overwintering refuge and its interaction with the surrounding landscape. Ecol Entomol 21:155-164

Costamagna AC, Landis DA, Brewer MJ (2008) The role of natural enemy guilds in Aphis glycines suppression. Biol Control 45:368-379

Cullen R, Warner KD, Jonsson M, Wratten SD (2008) Economics and adoption of conservation biological control. Biol Control 45:272-280

Danthanarayana W (1975) The bionomics, distribution and host range of the light brown apple moth, Epiphyas postvittana (Walk.) (Tortricidae). Austral J Zool 23:419-437

Denoth M, Frid L, Myers JH (2002) Multiple agents in biological control: improving the odds? Biol Control 24:20-30

Elton CS (1958) The ecology of invasions by animals and plants. Methuen and Co Ltd, London

Eubanks MD, Styrsky JD (2005) Effects of plant feeding on the performance of omnivorous 'predators'. In: Wäckers FL, van Rijn PCJ, Bruin J (eds) PlantProvided Food for Carnivorous Insects: a protective mutualism and its applications. Cambridge University Press, Cambridge, U.K., pp 148-177

Fiedler AK, Landis DA (2007a) Attractiveness of Michigan native plants to arthropod natural enemies and herbivores. Environ Entomol 36:751-765

Fiedler AK, Landis DA (2007b) Plant characteristics associated with natural enemy abundance at Michigan native plants. Environ Entomol 36:878-886 
Fiedler AK, Landis DA, Wratten SD (2008) Maximizing ecosystem services from conservation biological control: The role of habitat management. Biol Control $45: 254-271$

Finke DL, Denno RF (2004) Predator diversity dampens trophic cascades. Nature 429:407-410

Finke DL, Denno RF (2005) Predator diversity and the functioning of ecosystems: the role of intraguild predation in dampening trophic cascades. Ecol Lett 8:12991306

Finke DL, Denno RF (2006) Spatial refuge from intraguild predation: implications for prey suppression and trophic cascades. Oecologia 149:265-275

Finke DL, Snyder WE (2008) Niche partitioning increases resource exploitation by diverse communities. Science 321:1488-1490

Frank SD, Shrewsbury PM (2004) Effect of conservation strips on the abundance and distribution of natural enemies and predation of Agrotis ipsilon (Lepidoptera: Noctuidae) on golf course fairways. Environ Entomol 33:1662-1672

Gardiner MM, Landis DA, Gratton C, DiFonzo CD, O'Neal M, Chacon JM, Wayo MT, Schmidt NP, Mueller EE, Heimpel GE (2009a) Landscape diversity enhances the biological control of an introduced crop pest in the north-central U.S. Ecol Appl 19:143-154

Gardiner MM, Landis DA, Gratton C, Schmidt N, O'Neal M, Mueller E, Chacon J, Heimpel GE, Difonzo CD (2009b) Landscape composition influences patterns of native and exotic lady beetle abundance. Divers Distributions 15:554-564

Greathead DJ, Greathead AH (1992) Biological control of insect pests by insect parasitoids and predators: the BIOCAT database. Biocontrol News Inf 13:61N$68 \mathrm{~N}$ 
Griffiths GJK, Holland JM, Bailey A, Thomas MB (2008) Efficacy and economics of shelter habitats for conservation biological control. Biol Control 45:200-209

Gurr GM, Wratten SD (1999) 'Integrated biological control': a proposal for enhancing success in biological control. Int J Pest Manag 45:81-84

Gurr GM, Wratten SD (2000) Biological Control: Measures of Success. Kluwer Academic Publishers, Dordrecht, The Netherlands

Gurr GM, Wratten SD, Altieri MA (2004) Ecological Engineering for Pest Management. CSIRO Publishing, Collingwood, Australia

Gurr GM, Wratten SD, Barbosa P (2000) Success in conservation biological control of arthropods. In: Gurr GM, Wratten SD (eds) Biological Control: Measures of Success. Kluwer Academic Publishers, Dordrecht, The Netherlands, pp 105-132 Gurr GM, Wratten SD, Tylianakis JM, Kean J, Keller M (2005) Providing plant foods for natural enemies in farming systems: balancing practicalities and theory. In: Wäckers FL, van Rijn PCJ, Bruin J (eds) Plant-Provided food for Carnivorous Insects: a protective mutualism and its application. Cambridge University Press, Cambridge, U.K., pp 326-347

Heimpel GE, Jervis MA (2005) Does floral nectar imrpove biological control by parasitoids? In: Wäckers FL, van Rijn PCJ, Bruin J (eds) Plant-Provided food for Carnivorous Insects: a protective mutualism and its application. Cambridge University Press, Cambridge, U.K., pp 267-304

Hossain Z, Gurr GM, Wratten SD, Raman A (2002) Habitat manipulation in lucerne Medicago sativa: arthropod population dynamics in harvested and 'refuge' crop strips. J Appl Ecol 39:445-454

Irvin NA, Scarratt SL, Wratten SD, Frampton CM, Chapman RB, Tylianakis JM (2006) The effects of floral understoreys on parasitism of leafrollers 
(Lepidoptera: Tortricidae) on apples in New Zealand. Agric Forest Entomol 8:25-34

Isaacs R, Tuell J, Fiedler A, Gardiner MM, Landis DA (2009) Maximizing arthropodmediated ecosystem services in agricultural landscapes: the role of native plants. Front Ecol Environ 7:196-203

Jonsson M, Wratten SD, Landis DA, Gurr GM (2008) Recent advances in conservation biological control of arthropods by arthropods. Biol Control $45: 172-175$

Jonsson M, Wratten SD, Robinson KA, Sam SA (2009) The impact of floral resources and omnivory on a four trophic level food web. Bull Entomol Res 99:275-285

Kean J, Wratten S, Tylianakis J, Barlow N (2003) The population consequences of natural enemy enhancement, and implications for conservation biological control. Ecol Lett 6:604-612

Kruess A, Tscharntke T (1994) Habitat fragmentation, species loss, and biological control. Science 264:1581-1584

Landis DA, Wratten SD, Gurr GM (2000) Habitat management to conserve natural enemies of arthropod pests in agriculture. Annu Rev Entomol 45:175-201

Lavandero B, Wratten SD, Didham RK, Gurr GM (2006) Increasing floral diversity for selective enhancement of biological control agents: a double edged sward? Basic Appl Ecol 7:236-243

Lavandero B, Wratten SD, Shishehbor P, Worner S (2005) Enhancing the effectiveness of the parasitoid Diadegma semiclausum (Helen): Movement after use of nectar in the field. Biol Control 34:152-158

Lee JC, Heimpel GE (2005) Impact of flowering buckwheat on Lepidopteran cabbage pests and their parasitoids at two spatial scales. Biol Control 34:290-301 
Lee JC, Heimpel GE (2008) Floral resources impact longevity and oviposition rate of a parasitoid in the field. J Appl Ecol 77:565-572

Leung B, Finnoff D, Shogren JF, Lodge D (2005) Managing invasive species: Rules of thumb for rapid assessment. Ecol Econ 55:24-36

Losey JE, Denno RF (1998) Positive predator-predator interactions: enhanced predation rates and synergistic suppression of aphid populations. Ecology $79: 2143-2152$

Mack RN, Simberloff D, Lonsdale WM, Evans H, Clout M, Bazzaz FA (2000) Biotic invasions: causes, epidemiology, global consequences, and control. Ecol Appl 10:689-710

MacLeod A, Wratten SD, Sotherton NW, Thomas MB (2004) 'Beetle banks' as refuges for beneficial arthropods in farmland: long-term changes in predator communities and habitat. Agric Forest Entomol 6:147-154

Menzler-Hokkanen I (2006) Socioeconomic significance of biological control. In: Eilenberg J, Hokkanen HMT (eds) An ecological and societal approach to biological control. Springer, Dordrecht, The Netherlands, pp 13-25

Öberg S, Ekbom B, Bommarco R (2007) Influence of habitat type and surrounding landscape on spider diversity in Swedish agroecosystems. Agric Ecosyst Environ 122:211-219

Paoletti MG, Pimentel D (2000) Environmental risks of pesticides versus genetic engineering for agricultural pest control. J Agric Environ Ethics 12:279-303

Pfiffner L, Wyss E (2004) Use of sown wildflower strips to enhance natural enemies of agricultural pests. In: Gurr GM, Wratten SD, Altieri MA (eds) Ecological Engineering for Pest Management. CSIRO Publishing, Melbourne, Australia, pp $165-186$ 
Pickett CH, Bugg RL (1998) Enhancing biological control - habitat management to promote natural enemies of agricultural pests. University of California Press, Berkeley, U.S.A.

Pimentel D (1961) Species diversity and insect population outbreaks. Ann Entomol Soc Am 54:76-86

Pimentel D, Zuniga R, Morrison D (2005) Update on the environmental and economic costs associated with alien-invasive species in the United States. Ecol Econ $52: 273-288$

Polis GA, Strong DR (1996) Food web complexity and community dynamics. Am Nat 147:813-846

Prasad RP, Snyder WE (2006) Polyphagy complicates conservation biological control that targets generalis predators. J Appl Ecol 43:343-352

Ranjan R, Marshall E, Shortle J (2008) Optimal renewable resource management in the presence of endogenous risk of invasion. Ecol Econ 89:273-283

Rebek EJ, Sadof CS, Hanks LM (2006) Influence of floral resource plants on control of an armored scale pest by the parasitoid Encarsia citrina (Craw.) (Hymenoptera: Aphelinidae). Biol Control 37:320-328

Robinson KA, Jonsson M, Wratten SD, Wade MR, Buckley HL (2008) Implications of floral resources for predation by an omnivorous lacewing. Basic Appl Ecol 9:172-181

Rogers ME, Potter DA (2004) Potential for sugar sprays and flowering plants to increase parasitism of white grubs (Coleoptera: Scarabaeidae) by Tiphiid wasps (Hymenoptera: Tiphiidae). Environ Entomol 33:619-626

Root RB (1973) Organization of a plant-arthropod association in simple and diverse habitats: The fauna of collards (Brassica oleracea). Ecol Monogr 43:95-124 
Roschewitz I, Thies C, Tscharntke T (2005) Are landscape complexity and farm specialisation related to land-use intensity of annual crop fields? Agric Ecosyst Environ 105:87-99

Rosenheim JA, Wilhoit LR, Armer CA (1993) Influence of intraguild predation among generalist insect predators on the suppression of a herbivore population. Oecologia 96:439-449

Sandhu HS, Wratten SD, Cullen R, Case B (2008) The future of farming: The value of ecosystem services in conventional and organic arable land. An experimental approach. Ecol Econ 64:835-848

Scarratt SL (2005) Enhancing the Biological Control of Leafrollers (Lepidoptera: Tortricidae) using Floral Resource Subsidies in an Organic Vineyard in Marlborough, New Zealand. Dissertation, Lincoln University, Lincoln, New Zealand

Schellhorn NA, Bellati J, Paull CA, Maratos L (2008) Parasitoid and moth movement from refuge to crop. Basic Appl Ecol 9:691-700

Schmidt MH, Roschewitz I, Thies C, Tscharntke T (2005) Differential effects of landscape and management on diversity and density of ground-dwelling farmland spiders. J Appl Ecol 42:281-287

Schmidt MH, Thies C, Nentwig W, Tscharntke T (2008) Contrasting responses of arable spiders to the landscape matrix at different spatial scales. J Biogeography $33: 157-166$

Schmidt NP, O'Neal ME, Singer JW (2007) Alfalfa living mulch advances biological control of soybean aphid. Environ Entomol 36:416-424

Schmitz OJ, Suttle KB (2001) Effects of top-predator species on direct and indirect interactions in a food web. Ecology 82:2072-2081 
Scott RR (1984) New Zealand Pest and Beneficial Insects. Lincoln University, College of Agriculture, Lincoln, New Zealand

Shogren JF, Tschirhart JT (2005) Integrating ecology and economics to adress bioinvasions. Ecol Econ 52:267-271

Snyder WE, Snyder GB, Finke DL, Straub CS (2006) Predator biodiversity strengthens herbivore suppression. Ecol Lett 9:789-796

Spellman B, Brown MW, Mathews CR (2006) Effect of floral and extrafloral resources on predation of Aphis spiraecola by Harmonia oxyridis on Apple. BioControl 51:715-724

Stephens MJ, France CM, Wratten SD, Frampton C (1998) Enhancing biological control of leafrollers (Lepidoptera: Tortricidae) by sowing buckwheat (Fagopyrum esculentum) in an orchard. Biocontrol Sci Technol 8:547-558

Straub CS, Finke DL, Snyder WE (2008) Are the conservation of natural enemy biodiversity and biological control compatible goals? Biol Control 45:225-237

Straub CS, Snyder WE (2006) Species identity dominates the relationship between predator biodiversity and herbivore suppression. Ecology 87:277-282

Straub CS, Snyder WE (2008) Increasing enemy biodiversity strengthens herbivore suppression on two plant species. Ecology 89:1605-1615

Swinton SM, Lupi F, Robertson GP, Landis DA (2006) Ecosystem services from agriculture: Looking beyond the usual suspects. Am J Agric Econ 88:1160-1166

Thies C, Roshewitz I, Tscharntke T (2005) The landscape context of cereal aphidparasitoid interactions. Proc R Soc B Biol Sci 272:203-210

Thies C, Steffan-Dewenter I, Tscharntke T (2003) Effects of landscape context on herbivory and parasitism at different spatial scales. Oikos 101:18-25 
Thies C, Tscharntke T (1999) Landscape structure and biological control in agroecosystems. Science 285:893-895

Thomas MB, Wratten SD, Sotherton NW (1991) Creation of 'island' habitats in farmland to manipulate populations of beneficial arthropods: predator densities and emigration. J Appl Ecol 28:906-917

Thomas MB, Wratten SD, Sotherton NW (1992) Creation of 'island' habitats in farmland to manipulate populations of beneficial arthropods: predator densities and species composition. J Appl Ecol 29:524-531

Thomas SR, Goulson D, Holland JM (2001) Resource provision for farmland gamebirds: the value of beetle banks. Ann Appl Biol 139:111-118

Tompkins J-ML (2009) Endemic New Zealand plants for pest management in vineyards. 3rd International Symposium on Biological Control of Arthropods 234-245

Tscharntke T, Bommarco R, Clough Y, Crist TO, Kleijn D, Rand TA, Tylianakis JM, van Nouhuys S, Vidal S (2008) Conservation biological control and enemy diversity on a landscape scale. Biol Control 45:238-253

Tuell JK, Fiedler AK, Landis DA, Isaacs R (2008) Visitation by wild and managed bees (Hymenoptera: Apoidea) to Eastern U.S. native plants for use in conservation programs. Environ Entomol 37:707-718

Tylianakis JM, Didham RK, Wratten SD (2004) Improved fitness of aphid parasitoids receiving resource subsidies. Ecology 85:658-666

van Rijn PCJ, Sabelis MW (2005) Impact of plant-provided food on herbivorecarnivore dynamics. In: Wäckers FL, van Rijn PCJ, Bruin J (eds) PlantProvided Food for Carnivorous Insects: a Protective Mutualism and its Applications. Cambridge University Press, Cambridge, U.K., pp 223-266 
Wäckers FL (2004) Assessing the suitability of flowering herbs as parasitoid food sources: flower attractiveness and nectar accessibility. Biol Control 29:307-314

Wanner H, Gu H, Dorn S (2006) Nutritional value of floral nectar sources for flight in the parasitoid wasp, Cotesia glomerata. Physiol Entomol 31:127-133

Warner KD (2007) Agroecology in Action: Extending Alternative Agriculture through Social Networks. MIT Press, Cambridge, U.S.A.

Wei Q, Walde SJ (1997) The functional response of Typhlodromus pyri to its prey, Panonychus ulmi: the effect of pollen. Exp Appl Acarol 21:677-684

Wilby A, Thomas MB (2002) Natural enemy diversity and pest control: patterns of pest emergence with agricultural intensification. Ecol Lett 5:353-360

Yachi S, Loreau M (1999) Biodiversity and ecosystem productivity in a fluctuating environment: the insurance hypothesis. Proc Acad Nat Sci USA 96:1463-1468

Zeddies J, Schaab RP, Neuenschwander P, Herren HR (2001) Economics of biological control of cassava mealybug in Africa. Agric Econ 24:209-219 
Figure 1

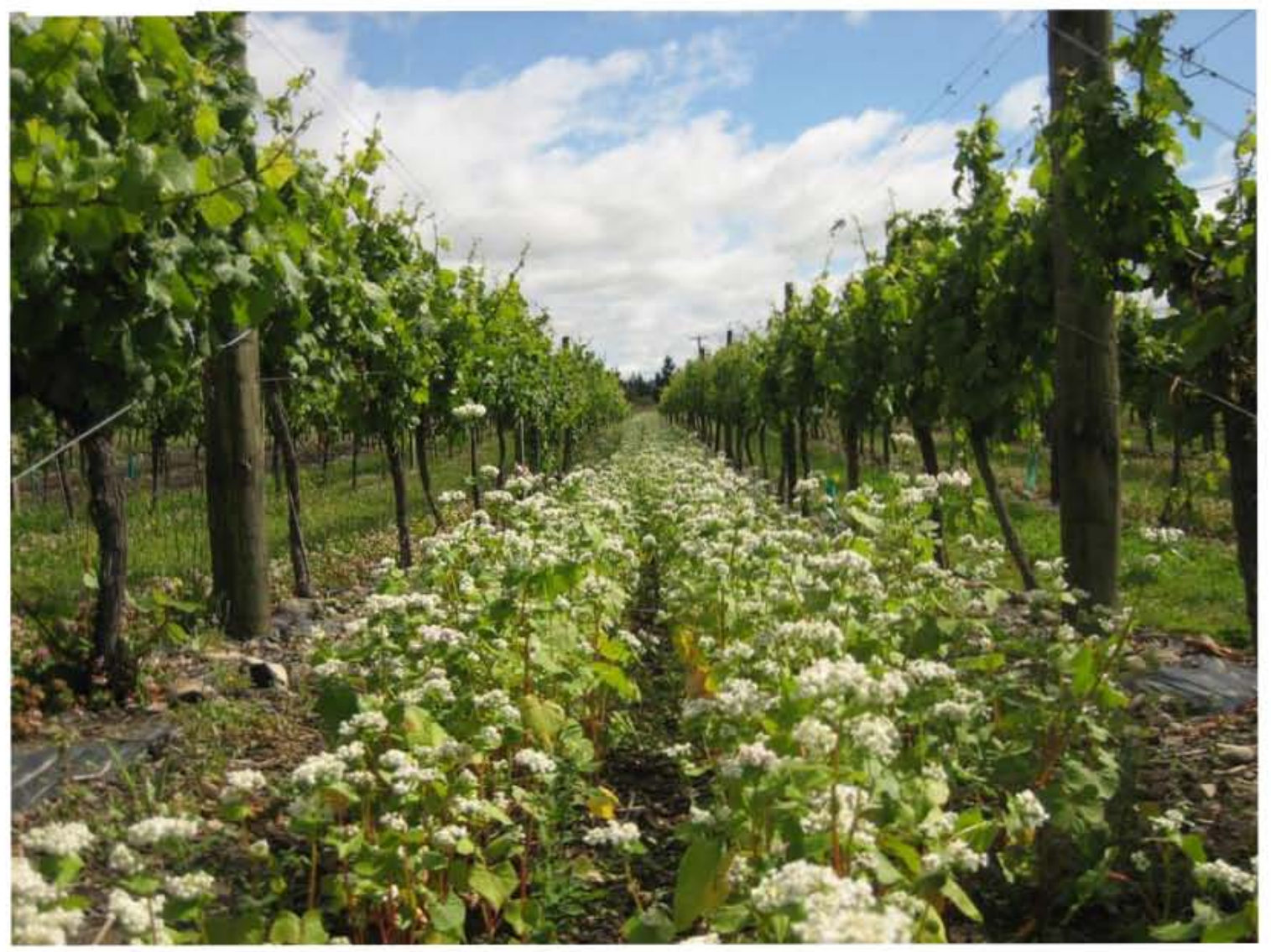


Figure 2

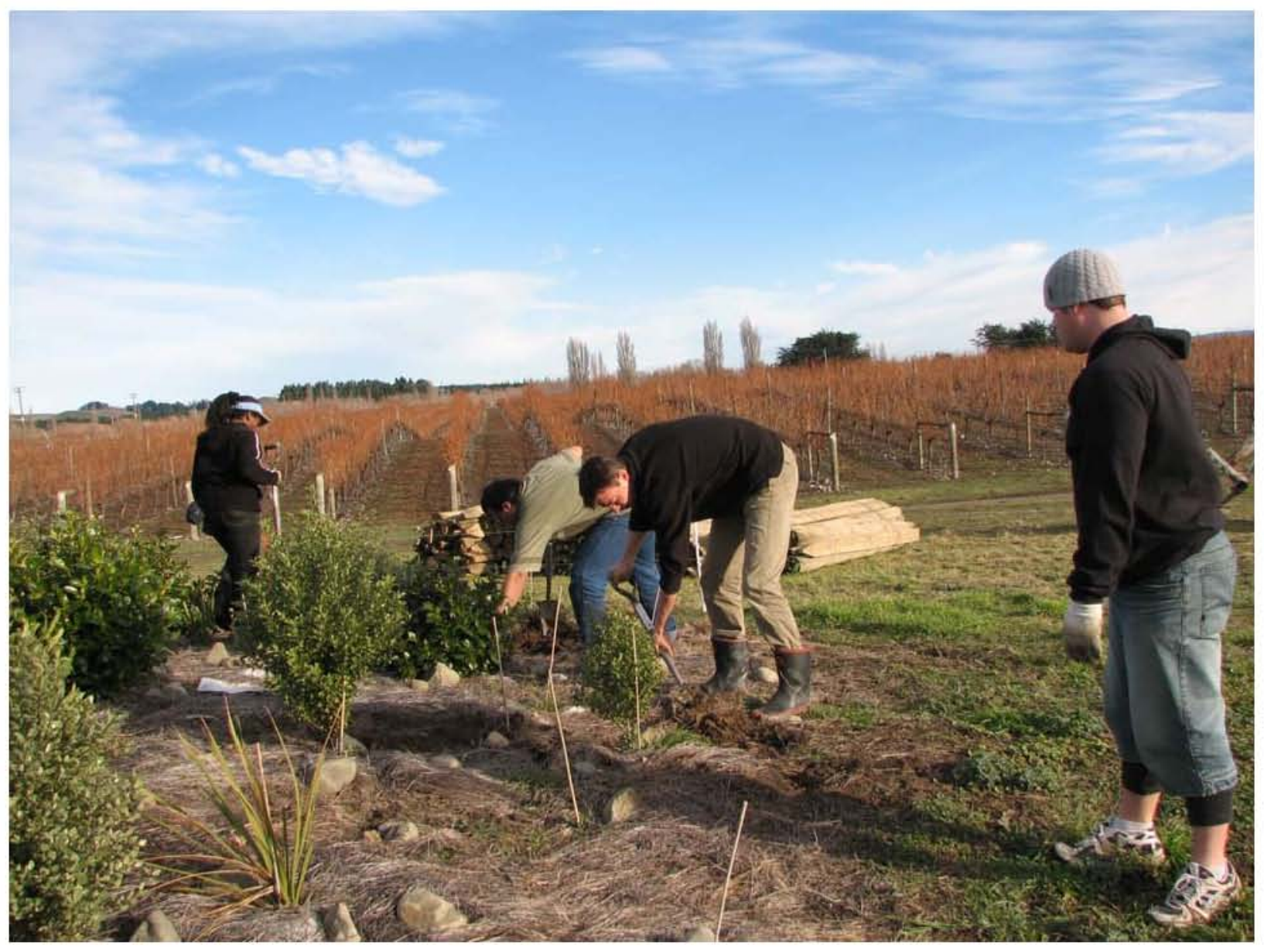


Figure 3

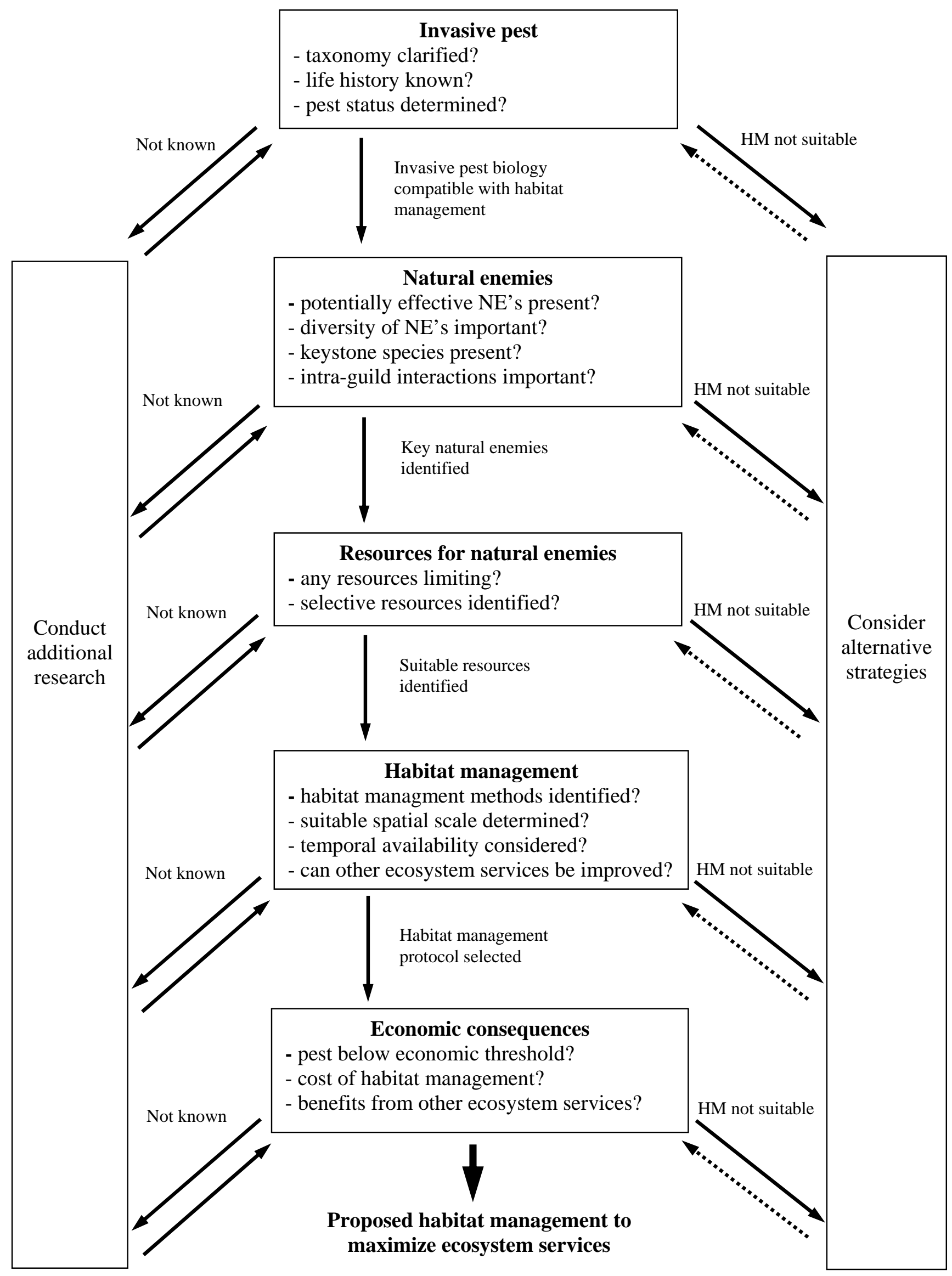




\section{Figure legends}

Fig. 1 Buckwheat, Fagopyrum esculentum, in a New Zealand vineyard to enhance biological control of leafrollers.

Fig. 2 Planting of native plant species in a vineyard in the Waipara valley, New Zealand.

Fig. 3 Flow diagram showing a generalized research strategy for developing habitat management approaches for invasive arthropods. Key research questions are identified by question marks (?). Before proceeding to the next step the key questions need to be addressed. To do this additional research might be needed. At each step it can be decided that habitat manipulation is not likely to be successful and alternative strategies need to be considered. 'HM' is abbreviation for Habitat Management and 'NE' stands for Natural Enemies. 
Table 1 Analysis of habitat manipulation studies to conserve natural enemies of invasive pests published between 1998 - 2007. A ‘+’ denotes a beneficial effect from a pest management point of view, '-‘a deleterious effect, '0' a non-significant effect and 'NA' that it was not studied.

Thus, for example, a '+' in the respective columns refers to an increase in enemy populations, predation/parasitism rates, crop yield and economic profit, and a decrease in pest populations and pest damage.

\begin{tabular}{|c|c|c|c|c|c|c|c|}
\hline Study & Enemy population & $\begin{array}{l}\text { Predation/ } \\
\text { parasitism } \\
\text { rate }\end{array}$ & $\begin{array}{l}\text { Pest } \\
\text { population }\end{array}$ & $\begin{array}{l}\text { Pest } \\
\text { damage }\end{array}$ & $\begin{array}{l}\text { Crop } \\
\text { yield }\end{array}$ & $\begin{array}{l}\text { Economic } \\
\text { assessment }\end{array}$ & Source \\
\hline EFN bearing peach trees in apple & NA & - & + & NA & NA & NA & Brown and Mathews 2007 \\
\hline Alfalfa as a cover crop in sovbean & + & NA & + & NA & _- & _- & Schmidt et al. 2007 \\
\hline Floral subsidies in vines & NA & + & 0 & NA & NA & NA & Berndt et al. 2006 \\
\hline Floral subsidies in apple & NA & + & + & 0 & NA & NA & Irvin et al. 2006 \\
\hline Beetle banks in mixed vegetables & + & 0 & NA & NA & NA & NA & Prasad and Snyder 2006 \\
\hline Floral subsidies in ornamental plants & NA & $0 /+$ & $0 /+$ & NA & NA & NA & Rebek et al. 2006 \\
\hline Floral subsidies in broccoli & NA & + & NA & NA & NA & NA & Lavandero et al. 2005 \\
\hline Floral subsidies in cabbage & NA & $0 /+$ & 0 & NA & NA & NA & Lee and Heimpel 2005 \\
\hline Floral subsidies in turf grass & NA & + & NA & NA & NA & NA & Rogers and Potter 2004 \\
\hline Floral subsidies in wheat & NA & + & NA & NA & NA & NA & Tylianakis et al. 2004 \\
\hline Floral subsidies in vines & + & 0 & NA & NA & NA & NA & Berndt et al. 2002 \\
\hline Floral subsidies in turf grass & $0 /+$ & 0 & NA & NA & NA & NA & Braman et al. 2002 \\
\hline 'Refuge' crop strips in lucerne & 0 & + & NA & NA & NA & NA & Hossain et al. 2002 \\
\hline Floral subsidies in potato & NA & + & - & - & NA & NA & Baggen and Gurr 1998 \\
\hline Floral subsidies in vines & + & + & NA & NA & NA & NA & Stephens et al. 1998 \\
\hline
\end{tabular}

